work who have raised themselves to an elevated position, on a mountain top as it were, from which they can clearly survey this great field of action. With quickened perceptions and trained intellects, they can bring to us tidings of surpassing interest as to whitherward we are traveling.

We count ourselves especially fortunate in having the privilege of hearing, as orator of the day, one whose exalted position gives him a clear view of the whole field of human endeavor. Your chairman presents Arthur T. Hadley, President of Yale University.

\section{The Professional Ideals of the Twentieth Century}

\section{By Arthur Twining Hadley}

A building like this is the best monument of what the twentieth century has accomplished. The really important part of the history of a nation is the development of its ideals and standards. The specific things that it does are important not so much for their own sake, but for the sake of the evidence they give as to the trend of a nation's thought. It is not the magnitude of the individual battles which makes a war worth reading about. It is the ideas under which the war is conducted and the constitutional principles for which it is fought. It is not the census figures which decide whether a nation is great or small. It is the industrial methods and educational ideas which these census figures indicate. And in like manner it is not the buildings and machines and railroads and mines which constitute the important part of the history of the engineering profession. A book might give a good description of a thousand of these great engineering works, and yet fail of being in any sense a true history of engineering progress. The thought of the successive builders and the influence of that thought upon the conduct and ideals of other men are the things that we really care about. The story of the concrete achievements that have dazzled the eye of the world is but the unimportant and superficial part of the history. The real thing for which we care, the thing that helps us to understand the past and inspires us with hope for the future, is the story of the men who did the things-their struggles and their discoveries, their trials and their successes.

The men who did more than anything else to make the nineteenth century different from the other centuries that went before it were its engineers. Down to the close of the eighteenth century the thinking of the country was dominated by its theologians, its jurists, and its physicians. These were by tradition the learned professions; the callings in which profound thought was needed; the occupations where successful men were venerated for their brains. It was reserved for the nineteenth century to recognize the dominance of abstract thought in a new field-the field of constructive effort-and to revere the trained scientific expert for what he had done in these lines. Engineering which a hundred years ago was but a subordinate branch of the military art, has become in the years which have since elapsed, a dominant factor in the intelligent practice of every art where power is to be applied with economy and intelligence.

A building like this is therefore the symbol of all that is most distinctive in the thought of the century that has gone by. A hundred years ago we might have had a building in honor of theologians or of lawyers or of physicians; but one that symbolized the achievements of the engineer was beyond man's dreams, because the world at large had neither felt the need of his work, nor dreamed how soon it would be seeking his leadership.

I have spoken of this building as a monument; but that is after all not the proper word. A monument implies that a man is dead, or at any rate that he has so nearly reached the limit of his growth that he might just as well be dead. Looked at in this way, the 
engineering profession wants no monument. It has not yet reached the limit of its growth. It has not come to the time when a complacent survey of the past will take the place of toilsome planning for the future. Not a headstone do we want, but a milestonea point at which our measurement of what has been already done, serves as an inspiration for the journey yet to be traversed. We may take this opportunity for a brief review of what has been done in engineering and other allied professions; but the engineer who is worthy of his calling will value that review most highly, if it is made a means of calling his attention to that which yet remains to be done.

A hundred years ago there was a sharp separation between scientific theory and commercial practice. There was not a great deal of science anyway, outside of mathematics and astronomy; and what there was was underrated by men of affairs. In those days when a man said he was practical it meant that he was not theoretical; that he didn't know science, and didn't want to know it, and didn't want to have any man around that did know it. The men of that day trusted to two guides; inherited prejudice, and individual experience. The more enlightened among them used experience to correct prejudice; the rank and file of them used experience to reinforce prejudice; and that was about all the difference. The value of generalizations, except in religion and in statecraft, and in some few branches of medicine, was not recognized by anybody.

The great element of progress in the nineteenth century has been the recognition on the part of mankind in general, of the value of scientific generalizations in every department of human conduct. Our science has become sounder, our understanding of its applications clearer, and the public has recognized that scientific conduct of a business means the substitution of universal experience, learned with difficulty and applied with toil, for the narrower range of individual experience which was at the disposal of the socalled practical men of fifty or a hundred years ago. Of this change the engineer is the representative and the leader. He it is that makes physical science in its various lines applicable to the complex problems of construction and development. He it is who has paved the way for the recognition of the technologist and the expert in every line of human industry. $\mathrm{He}$ it is who has shown how mathematics, instead of being an abstract discipline, remote from every day human affairs may become the means of applying truths for a long time remote and undiscovered, to the every day affairs of the world in which we live. Not the buildings that you have built, gentlemen; not the railroads that you have planned; not the machines that you have invented, represent your greatest achievement. Yours is the proud boast of having in one brief century established science as the arbiter of the material affairs of mankind, and of having enforced her worship upon a world once reluctant, but now gloriously admiring.

Well, then, you will ask: is there anything which remains to be done comparable in importance to this? Yes, there is. An equally large part - perhaps in one sense a much larger part- of your professional duty yet remains to be accomplished. It is not enough to have technical training. It is not enough to know the special sciences on which the practice of a profession is based. A man ought to have clear conceptions of the public service which his profession is based. A man ought to have clear conceptions of the public service which his profession can render, and the public duty which its members owe. Thus, and thus only, can the engineer, the lawyer, the physician, or a member of any other learned profession, rise to the full dignity of his calling.

For there are two quite distinct qualities which must be combined in order to secure the best professional ser- 
vices; two quite distinct tests which work must meet in order to be pronounced first class. One of these is the technieal standard; the other, for want of better word, may be called the ethical standard. The man who wishes to build a good railroad must not only lay it out according to the rules of the surveyor's art, with proper curves and grades, and bridges which will not fall, but he must also have intelligent regard to the needs of the population, the safety of travel, and the many other factors which determine whether a railroad shall be a work of public use or a source of industrial bickering and financial disaster. This combination of public and private demands is not peculiar to engineering. It can be illustrated in every other profession of importance. It is not enough for the lawyer to give advice which shall be technically sound, and which shall enable his clients to keep out of jail. $\mathrm{He}$ must learn to take a large view of the law as a means of public service instead of private gain. It is not enough for the physician to know how to cure specific diseases. He must know how to care for the larger problems of public health, and to use the resources of the community in a way to meet as fully as possible its sanitary needs.

This larger view of professional obligations is not so fully recognized as it should be. We have in the nineteenth century made so much progress in the technical training of doctors and lawyers and engineers that we sometimes forget that there is need of anything more than technical training. We have let the old idea of public leadership, which was prominent in the minds of the great professional men of past centuries, give place to another and narrower ideal which is fully satisfied when a man has made himself a technical expert. Many a man of real eminence in his calling deliberately rejects the wider conception of professional duty which I have here indicated. Perhaps he recognizes the claims of public service; perhaps he does not, but in any event he believes that these claims rest upon him as a man rather than as an engineer or a lawyer. In his professional capacity he says he is hired not to tell what the law ought to be, but what it is; not to advise how a railroad can do the most public service, but how certain men with certain ideas of their own can best use the differential calculus to get these ideas carried out. This is perhaps the prevalent view of professional ethics to-day. I believe that it is a wrong view, which must menace not only the influence and standing of the professions themselves, but the general interests of the republic.

In the first place, a man who believes that he is hired to carry out another man's ideas can never claim a position of actual leadership. $\mathrm{He}$ remains a paid servant-highly paid, doubtless, because he is possessed of a kind of skill which is very unusual, but nevertheless a servant, bound to carry out the wishes of his master. A group of professional men which regards this as a proper view thereby forfeits the claim to stand in the first rank socially and politically, and voluntarily accepts a position of the second rank. I do not believe that the engineers of America want to do this. It has been said that engineering is the handmaiden of commerce; but I do not believe that the men who have planned and dedicated this building will be satisfied with any handmaidenly conceptions of what their successors ought to be. If for a moment, in our zeal for new technical developments, we have let our responsibilities as public servants fall out of our hands, I feel sure that we shall be ready to take them up again as soon as our eyes are opened to the real situation.

For mere technical achievement is not the thing that endures. Among the peoples of the ancient world, I suppose that there were no engineers equal to those of Egypt Considering the means at their command, the 
things that they did were absolutely extraordinary. They did some things which, even with the means at our command, we can hardly duplicate. But they used their abilities in the service of a dominant priestly caste; and therefore, while their work fills us witk admiration, it does not appeal to us as does the work of the Roman engineers a few centuries later, who built roads and aqueducts and bridges, and thus took the lead side by side with the Roman lawyers in establishing the basis of modern civilization. The roads and bridges of Rome, simple and straightforward as they are, constitute a more enduring monument to the Roman engineers than all the obelisks and pyramids that were ever erected.

For their own sake, then, and for the sake of the enduring quality of their work, we can appeal to the engineers and lawyers and physicians to see that it is adapted to public ends. We can reinforce this appeal by a yet stronger one on behalf of the American commonwealth as a whole. For the development of technical ideals and standards in our various professions during the last few centuries, to the neglect of exclusion of ethical ones, is constituting a very serious public danger.

A commonwealth like that of the United States is necessarily governed by public opinion. Courts may formulate this opinion. Legislatures may pass rules to give effect to it. Police may enforce its demands against the recalcitrant. But the governing power rests in the intelligent public opinion itself. When that opinion ceases to be intelligent and powerful, freedom becomes a mere name. Now, a serviceable public opinion of this kind can only be formed when intelligent people, technically trained for different lines of life, seriously try to find out how their work can be made to meet the public needs. They are the only ones who can do this well. If it is done by anybody else it will be done badly. If the lawyers as a class try to keep the law in line with the demands of intelligent public opinion, we can get good law. But if lawyers are content to see the law perverted to private ends, and judges take refuge in technical construction of precedents, without full regard to the needs of the existing situation, legislatures will step in to create a chaos of conflicting laws which are worse than no law at all. In like manner, if our engineers get their own minds clear, and get the public mind clear, as to the political economy of the properties entrusted to their charge and the ethics of their management, they can forestall these conflicts which now threaten to break out at every moment. But if the members of a profession whose advice is necessary is order to a clear understanding and wise settlement of these problems retire from the field of action, the matter will be settled by those whose interēsts are more selfish and less farsighted. There are three professions to-day which do not regard themselves as servants, but as masters-the financier, the journalist and the politician. If the engineer and the lawyer accept positions as servants, simply putting their technical knowledge at the disposal of merchant, journalist, or politician who will pay the highest price for it, it is not simply a confession of inferiority, it is a dereliction of public duty.

Do you say that it is impossible for a single man or a group of men to remedy these evils? Look at the career of Albert Fink, who in 1874, when he was an engineer on the Louisville and Nashville Railroad, made a study of the cost of transportation which has been at the basis of all the intelligent management of the traffic departments of railroads from that time to this.

Of course, Albert Fink was a rare man. He could do things that some of the rest of us cannot. But, I verily believe, that if our profession could awake to the necessity of broad ideals like those of Fink the greatest dangers 
which threaten the American commonwealth would be fairly met, and the men who met them would be given the position of power and trust which they had proved themselves worthy to hold. Nobody is satisfied to-day with the struggle between individualities and socialism, between financier and politician, between Wall street and Washington. The men who are engaged in this conflict are for the most part heartily sick of it. Let a man or group of men arise who add to their technical knowledge, a readiness to use that knowledge in the public service, and people will be ready to put them in charge of affairs and follow where they lead. We have outgrown the day when a little common sense was sufficient for managing the affairs of the nation. They are become too complex; and this complexity gives the engineer, if he will add to his training in mathematics a training in ethics and political economy and the fundamental principles of the law, an opportunity such as never before existed to claim and receive the position which rightfully belongs to him.

There arises now and then among our engineers a man with this quality of looking into the future-call it genius, call it insight, call it imagination. One of your own members said in a memorable speech that the thing which distinguishes a man of the first rank in his profession from a man of the second rank is the possession of this quality of imagination. Unfortunately it is rare. We cannot all of us have it. But we can have more of it than we now have, if we will modify our training and widen our standards of professional success. Excellent as is the course in our technical schools, it does tend to have a narrowing effect instead of a broadening one. The ideals of our engineering societies are high, but they are not always as broad as they might be. The widening of the course in the schools and greater readiness in our associations to recognize services which we now call non-professional, will, I am convinced, do more for the engineers and more for the community than would be represented by ten years' progress in mining or machinery and the various developments of applied science.

We celebrate to-day, and we are justified in celebrating, the recognition of science as a necessary guide in the conduct of the material affairs of each man's business. Half a century hence, when our descendants shall meet in this building or some yet greater building, I am confident that they will celebrate a yet greater thingthe recognition of the right of men of science to take the lead in enlightening the thought of the people on public affairs, and the responsibilty of filling the highest positions in the service of the commonwealth.

[Music. Hallelujah Chorus. Händel.]

Formal Dedication of the Building

Charles Wallace Hunt: The dedicatory ceremonies appointed for the day having been completed, I declare that this building is duly dedicated to the advancement of the engineering arts and sciences in all their branches

\section{EVENING RECEPTION}

9.00 p.m.-10.30 p.m. General reception in the main auditorium.

10.00 p.m. Reception by the officers and councils of the founder societies in their respective headquarters. The American Institute of Mining Engineers, ninth floor. The American Institute of Electrical Engineers, tenth floor; The American Society of Mechanical Engineers, eleventh floor.

Refreshments were served during the evening on the fifth floor.

Music in main auditorium, and on fifth, and library floors.

Wednesday, April 17, 1907, at 3 p. m.

JонN W. LIEB, JR.: In opening the dedicatory exercises on Wednesday, April 17, 1907, at 3 p.m., John W. Lieb, Jr., 